\title{
ACCLIMATION OF POPLAR TREES \\ TO HEAVY METALS IN POLLUTED HABITATS: \\ I. CARBOHYDRATE METABOLISM IN FINE ROOTS OF POPULUS DELTOIDES*
}

\author{
GABRIELA LORENC-PLUCIŃSKA, KRZYSZTOF STOBRAWA \\ Institute of Dendrology, Polish Academy of Sciences \\ Parkowa 5, 62-035 Kórnik, Poland \\ e-mail: glp@man.poznan.pl
}

(Received: June 3, 2004. Accepted: December 12, 2004)

\begin{abstract}
Concentrations of total nonstructural carbohydrates (TNC), soluble carbohydrates, starch, sucrose, glucose, fructose, raffinose, galactose, stachyose, mannitol and specific activities of soluble acid (AI) and neutral (NI) invertases, sucrose synthase (SuSy), hexokinase (HK), fructokinase (FK), glyceraldehyde 3-phosphate dehydrogenase (GAPDH) and glucose 6-phosphate dehydrogenase (G6PDH) were analyzed in fine roots of Populus deltoides Bartr. ex Marsh growing at a polluted site (near copper smelters) and a control site (free from heavy pollution). Also chemical properties of the soil from both sites were assessed. In comparison with the control, fine roots from the polluted site contained greater concentrations of TNC, soluble sugars, starch and sucrose but less hexoses, so they had higher values of sucrolysis index (sucrose/hexoses). The activity of AI, NI and SuSy declined insignificantly, while specific activities of HK, FK, GAPDH and G6PDH were significantly inhibited. The results suggest that a long-term heavy metal stress leads to an accumulation of carbohydrates and altering activities of glycolysis and the oxidative pentose phosphate pathway in fine roots.
\end{abstract}

KEY WORDS: Populus deltoides Bartr. ex Marsh, fine roots, starch, sugars, sucrose breakdown, glycolysis, heavy metals.

\section{INTRODUCTION}

Many publications document the harmful effects of heavy metals on plant growth, and roots are the plant organs that suffer frequently from it (Breckle 1991). A large group of heavy metals can directly or indirectly alter root elongation and biomass (Arduini et al. 1995; Di Baccio et al. 2003), disturb water relations and mineral nutrition (Gouia et al. 2000), cause oxidative damage of tissues (Landberg and Greger 2002; Pukacki and Kamińska-Rożek 2002; Schützendübel and Polle 2002), affect the activity of some enzymes (Arisi et al. 2000; Gouia et al. 2000; Lagriffoul et al. 1998; Mattioni et al. 1997; Van Assche and Clijsters 1990), and change carbohydrate levels (Brunner et al. 2002; Greger and Bertell 1992; Jha and Dubey 2004).

Among carbohydrates, the most important role in plants is played by sucrose. It is the major energy-storage compound, the main sugar transported in sieve tubes, a substrate for biosynthesis of amino acids, fatty acids and many other

* Preliminary results of this study were presented at an International Conference on Eco-engineering, held on 13-17 September 2004 in Thessaloníki, Greece plant components, and a compound affecting the mechanisms of osmoregulation (Farrar et al. 2000; Koch 2004; Roitsch 1999). Moreover, sucrose induces signal transduction and - like glucose - is a signal molecule, controlling directly or indirectly the expression of respective genes and enzymatic activity, transmitting information on the course of physiological processes in individual source and sink organs (Ho et al. 2001; Koch 2004; Smeekens 2000).

In plant roots, sucrose is chiefly degraded and the resultant hexoses and their derivatives are used as sources of energy and carbon skeletons, which are necessary for growth, development and accumulation of storage compounds (Sturm and Tang 1999).

Little is known about the effects of heavy metals on carbohydrate metabolism in the roots. The available data are most often results of studies performed under controlled, laboratory conditions, concerning mainly changes in concentrations of soluble sugars and starch (Costa and Spitz 1997; Greger and Lindberg 1986; Kim et al. 2003). Therefore to obtain more conclusive information on alterations induced by heavy metals in carbohydrate metabolism, we intended to study changes in the activity of enzymes involved in sucrolysis and glycolysis and the levels of particu- 
lar sugars in fine roots of Populus deltoides trees growing for several decades at two sites: one located in the buffer zone of copper smelters and the other in an area free from direct industrial pollution. Poplars were chosen for this study because of their economic importance (Karacic et al. 2003), resistance to atmospheric pollution (Szadel et al. 2003), ability to survive and grow on metal-contaminated soils, and potential use for phytoremediation (Di Baccio et al. 2003; Dinelli and Lombini 1996; Pulford and Watson 2003; Robinson et al. 2000; Vandecasteele et al. 2002).

\section{MATERIALS AND METHODS}

\section{Site description}

Copper smelters and refineries (KGHM Polska Miedź S.A.) at Głogów $\left(51^{\circ} 40^{\prime} \mathrm{N}, 16^{\circ} 05^{\prime} \mathrm{E}\right)$ consist of two parts: the first ("Głogów I") operating since 1971, and the other ("Głogów II"), since 1979. The technology is based on melting copper concentrates in shaft furnaces in "Głogów I", and in fluidized-bed furnaces in "Głogów II". The main types of pollutants emitted by the "Głogów" smelters include: $\mathrm{CO}$, particulates containing metals, and $\mathrm{H}_{2} \mathrm{SO}_{4}$. In the last few years the emission of pollution into the air declined, mainly thanks to the replacement of shaft furnaces by fluidized-bed furnaces in "Głogów I", installation of equipment for de-sulfuration of fumes, and modernization of the sulfuric acid factory. Mean annual concentrations of $\mathrm{SO}_{2}$ in the zone surrounding the "Głogów" smelters do not exceed the level allowed in the EU $\left(20 \mu \mathrm{g} \mathrm{m}^{-3}\right.$ ) (source: KGHM Polska Miedź S.A., www.kghm.pl).

In the spring of 1977, workers of the Institute of Dendrology established experimental plots on former farmland in buffer zone A of the "Głogów" smelters (i.e. about 1000 $\mathrm{m}$ away from the source of pollution), and planted there hardwood cuttings of several poplar species originating from the collection "Populetum" of the Institute. Control plots were established at Kórnik $\left(52^{\circ} 15^{\prime} \mathrm{N}, 17^{\circ} 04^{\prime} \mathrm{E}\right)$, in a habitat free from direct industrial pollution. Thus the trees growing on both plots derive from the same source material and because of their genetic homogeneity, are good objects for the investigations. Any differences in metabolic activity should result from differences in environmental conditions.

Since 1977, many of the trees planted near copper smelters (in the polluted site) have died spontaneously or have been felled for various reasons (sometimes scientific). At present, poplar trees growing there are characterized by satisfactory growth in height, but their radial growth is slower, tree crowns are poorly developed, and dead branches are not shed for long periods. Their leaves develop in spring relatively quickly and abundantly, but are shed quickly and are prone to infection by various pathogens. However, in the last three growing seasons, we did not observe on leaf blades any discoloration or injuries characteristic of industrial pollution.

\section{Plant material}

For this study, six cottonwoods (Populus deltoides Bartr. ex Marsh) were selected at each site. Fine roots $(\varnothing<1-2$ $\mathrm{mm})$ were used as experimental material. Mycorrhizae associated with roots were regarded as parts of the roots. At the polluted and control sites, samplings of the fine roots were done on October 9-10, 2002 at the same time of the day (between 1100 and $1230 \mathrm{~h}$ ). Fine roots were collected from the upper soil horizon (10-20 cm depth), after removal of $\mathrm{A}_{0}$. After collection, the roots were quickly washed in water, manually separated from the soil and from roots of annual plants, then soaked in liquid nitrogen and kept at $-80^{\circ} \mathrm{C}$ till required. All visibly dead roots were removed.

\section{Mineral analysis of the soil}

The chemical composition of the soil from the rooting zone of each of the six selected trees was analyzed according to standard research methods. Soil samples were airdried, crushed, and sieved to $1 \mathrm{~mm}$ particle size with a plastic sieve. Total concentrations of $\mathrm{Cu}, \mathrm{Cr}, \mathrm{Ni}, \mathrm{Fe}, \mathrm{Ca}, \mathrm{Mn}$, $\mathrm{Mg}, \mathrm{K}, \mathrm{P}, \mathrm{Pb}, \mathrm{Zn}$, and $\mathrm{Cd}$ in the soil were determined in the solution obtained after perchloric acid digestion. Concentrations of the forms of metals available to plants were determined after extraction with EDTA. Metals were analyzed by either flame or graphite furnace atomic absorption spectrometry (AAS). $\mathrm{N}$ was measured by the Kjeldahl method and $\mathrm{S}$ by the coulometric method. Concentrations of $\mathrm{S}-\mathrm{SO}_{4}, \mathrm{~N}-\mathrm{NO}_{3}$ and $\mathrm{N}-\mathrm{NH}_{4}$ were determined on an ionexchange chromatograph (Dionex-100). Analyses of elements were made in the Institute of Botany, Polish Academy of Sciences, Kraków, Poland. Soil pH was assessed in bi-distilled water and in $\mathrm{KCl}$ solution.

\section{Carbohydrate analysis}

Total nonstructural carbohydrates (soluble and starch) extractions and determinations were performed as previously described (Lorenc-Plucińska et al. 2001). To extract sucrose, glucose, fructose, raffinose, stachyose, galactose and mannitol, root tissues were homogenized in a mixture of methanol, chloroform and water $(12: 5: 3 \mathrm{v} / \mathrm{v})$, and quantitatively determined using a HPLC system (Waters) fitted with a Sugar Pack I column (Waters) and a refracting index detector (Waters). A detailed description of the procedure is given by Lorenc-Plucińska et al. (2001).

\section{Enzyme extractions}

All procedures were carried out at 0 to $4^{\circ} \mathrm{C}$. Tissue preparation for enzyme extraction was performed according to the procedure of Copeland and de Lima (1992) with minor modifications. Two-gram frozen root samples were ground in a mortar with $5 \mathrm{ml}$ of grinding medium containing 50 mM Tris-HCl (pH 7.5), 1 mM EDTA, 2 mM DTT, 6\% (w/v) PVP-40, and 1\% (w/v) PEG-20M. The extract was filtered through Miracloth and centrifuged at $20000 \mathrm{~g}$ for $20 \mathrm{~min}$. With the exception of sucrose synthase, extractable activities of enzymes were assayed after desalting the supernatant through BioRad Econo-Pac columns equilibrated with $50 \mathrm{mM}$ Tris- $\mathrm{HCl}(\mathrm{pH} 7.5)$. The activity of sucrose synthase was estimated in crude tissue extracts because after desalting the activity of this enzyme was often below detection level.

\section{Enzyme assays}

Sucrose synthase (SuSy; EC 2.4.1.13) was assayed in the cleavage direction according to Huber (1989). Acid (AI) and alkaline (NI) invertases (EC 3.2.1.26), fructokinase (FK; EC 2.7.1.4) and glucose 6-phosphate dehydrogenase (G6PDH; EC 1.1.1.49) were assayed following the method reported by Copeland and de Lima (1992). The activity of 
hexokinase (HK; EC 2.7.1.1) was determined as described by Sung et al. (1993), while glyceraldehyde 3-phosphate dehydrogenase (GAPDH; EC 1.2.1.12) was estimated with the method of Zammit and Copeland (1991). The enzyme activity was referred to the protein content of each sample. Soluble proteins were determined in the supernatant by the Bradford dye-binding assay (Bradford 1976), using a commercial dye reagent from BioRad and bovine serum albumin as a standard.

\section{Statistics}

All results are presented as the mean values $( \pm \mathrm{SE})$ obtained from at least six independent replicates. The exact number of replicates is given in the tables. Data were analyzed with STATISTICA 6.1 software (Statsoft Inc., USA). Means from the control and polluted site were compared by using the t-Tukey HSD (Tukey's honestly significant difference) test.

\section{RESULTS}

\section{Soil characteristics}

Results of the assessment of $\mathrm{pH}$ and total and EDTAextractable fractions of the selected elements in soil samples from the polluted site (near copper smelters "Głogów") and the control site (Kórnik) are shown in Tables 1 and 2. The soil from the polluted site was weakly acid and had a lower $\mathrm{pH}$ than the soil from the control site. Total $\mathrm{N}$, $\mathrm{N}-\mathrm{NH}_{4}$ and $\mathrm{N}-\mathrm{NO}_{3}$ concentrations as well as total $\mathrm{Ca}$ and $\mathrm{Ca}-\mathrm{EDTA}$ extractable in the soil samples from the polluted site were also lower than in the control site. For mean concentrations of $\mathrm{S}, \mathrm{K}, \mathrm{P}$ and $\mathrm{Mg}$, the reverse was observed (Table 1).

The concentrations of heavy metals in soil samples from the polluted site were much higher than in the control site: 258 times for $\mathrm{Cu}, 37$ times for $\mathrm{Pb}, 3.6$ times for $\mathrm{Ni}, 3.2$ times for Cd, 2.9 times for $\mathrm{Zn}, 2.3$ times for Cr, 1.9 times for $\mathrm{Mn}$ and 1.7 times for Fe (Table 2). Except for $\mathrm{Cr}, \mathrm{Fe}, \mathrm{Ni}$ and $\mathrm{Mn}$, similar differences were noted for the concentrations of EDTA-extractable fractions of the different metals (Table 2).

TABLE 1. Mineral composition and $\mathrm{pH}$ of soil samples from the rooting zone of Populus deltoides in the polluted and control sites ${ }^{\mathrm{a}}$.

\begin{tabular}{|c|c|c|}
\hline Soil parameters & Control site & Polluted site \\
\hline $\mathrm{N}$ total $(\%)$ & $0.22 \pm 0.004$ & $0.14 \pm 0.007 * * *$ \\
\hline $\mathrm{N}-\mathrm{NH}_{4}\left(\mu \mathrm{g} \mathrm{g}^{-1}\right)$ & $15.32 \pm 0.44$ & $4.30 \pm 0.67 * * *$ \\
\hline $\mathrm{N}-\mathrm{NO}_{3}\left(\mu \mathrm{g} \mathrm{g}^{-1}\right)$ & $11.47 \pm 0.17$ & $9.72 \pm 0.676^{* *}$ \\
\hline $\mathrm{S}$ total $(\%)$ & $0.03 \pm 0.001$ & $0.04 \pm 0.001 * * *$ \\
\hline $\mathrm{S}-\mathrm{SO}_{4}\left(\mu \mathrm{g} \mathrm{g}^{-1}\right)$ & $27.25 \pm 1.83$ & $23.67 \pm 1.15$ \\
\hline Ca total $\left(\mu \mathrm{g} \mathrm{g}^{-1}\right)$ & $9044 \pm 282$ & $2571 \pm 105^{* * *}$ \\
\hline $\mathrm{Ca}-\mathrm{EDTA}\left(\mu \mathrm{g} \mathrm{g}^{-1}\right)$ & $5296 \pm 70$ & $606 \pm 31.8 * * *$ \\
\hline $\operatorname{Mg}$ total $\left(\mu g^{-1}\right)$ & $821.7 \pm 22.7$ & $1524 \pm 31.7 * * *$ \\
\hline $\mathrm{Mg}-\mathrm{EDTA}\left(\mu \mathrm{g} \mathrm{g}^{-1}\right)$ & $56.82 \pm 2.03$ & $54.88 \pm 2.3$ \\
\hline $\mathrm{K}$ total $\left(\mu \mathrm{g} \mathrm{g}^{-1}\right)$ & $716 \pm 17.6$ & $2224 \pm 35^{* * * *}$ \\
\hline $\mathrm{K}$ - EDTA $\left(\mu \mathrm{g} \mathrm{g}^{-1}\right)$ & $95.37 \pm 2.46$ & $208.4 \pm 9.04 * * *$ \\
\hline$P$ total $\left(\mu g g^{-1}\right)$ & $506.7 \pm 51.7$ & $543.3 \pm 26.1$ \\
\hline $\mathrm{P}-\mathrm{PO}_{4}\left(\mu \mathrm{g} \mathrm{g}^{-1}\right)$ & $166.5 \pm 6.44$ & $221.5 \pm 21.8 *$ \\
\hline $\mathrm{pH} w \mathrm{H}_{2} \mathrm{O}$ & $7.45 \pm 0.026$ & $6.53 \pm 0.07 * * *$ \\
\hline $\mathrm{pH}$ w $\mathrm{KCl}$ & $7.23 \pm 0.024$ & $5.80 \pm 0.13^{* * * *}$ \\
\hline
\end{tabular}

a Mean values \pm SE from 9 random samples. $*, * *, * * *$ significantly different from the control at $\mathrm{P} \leq 0.05, \mathrm{P} \leq 0.01$ and $\mathrm{P} \leq 0.001$, respectively.
TABLE 2. Heavy metals in soil samples from the rooting zone of Populus deltoides in the polluted and control sites ${ }^{\mathrm{a}}$.

\begin{tabular}{|c|c|c|}
\hline Heavy metals $\left(\mu g^{-1}\right)$ & Control site & Polluted site \\
\hline Cd total & $0.36 \pm 0.029$ & $1.10 \pm 0.046^{* * *}$ \\
\hline $\mathrm{Cd}-\mathrm{EDTA}$ & $0.09 \pm 0.002$ & $0.35 \pm 0.022 * * *$ \\
\hline $\mathrm{Pb}$ total & $11.59 \pm 0.225$ & $411.13 \pm 9.33$ *** \\
\hline $\mathrm{Pb}-$ EDTA & $4.87 \pm 0.11$ & $255.3 \pm 16.6^{* * * *}$ \\
\hline Zn total & $31.75 \pm 0.91$ & $98.02 \pm 4.6 * * *$ \\
\hline $\mathrm{Zn}$ - EDTA & $6.56 \pm 0.39$ & $36.54 \pm 2.06 * * *$ \\
\hline $\mathrm{Cu}$ total & $4.53 \pm 0.15$ & $1174.75 \pm 69.93 * * *$ \\
\hline $\mathrm{Cu}-\mathrm{EDTA}$ & $2.31 \pm 0.09$ & $849.7 \pm 52.7 * * *$ \\
\hline Cr total & $13.08 \pm 0.31$ & $31.38 \pm 0.48 * * *$ \\
\hline $\mathrm{Cr}-\mathrm{EDTA}$ & $0.54 \pm 0.034$ & $0.25 \pm 0.013 * * *$ \\
\hline Ni total & $2.77 \pm 0.057$ & $9.72 \pm 0.39 * * *$ \\
\hline $\mathrm{Ni}$ - EDTA & $0.86 \pm 0.021$ & $0.90 \pm 0.019$ \\
\hline Fe total & $6014 \pm 58$ & $10737 \pm 112^{* * *}$ \\
\hline $\mathrm{Fe}-\mathrm{EDTA}$ & $581.9 \pm 10.1$ & $214.2 \pm 8.3 * * *$ \\
\hline Mn total & $170.7 \pm 4.3$ & $339.9 \pm 4.9 * * * *$ \\
\hline Mn - EDTA & $118.5 \pm 1.7$ & $124.8 \pm 3.7$ \\
\hline
\end{tabular}

a Mean values \pm SE from 9 random samples. $* * *$ significantly different from the control at $\mathrm{P} \leq 0.001$.

\section{Carbohydrate concentrations}

Concentrations of total nonstructural carbohydrates (TNC, i.e. the sum of concentrations of soluble carbohydrates and starch), starch, sucrose and galactose were higher in fine roots of trees from the polluted site than in the control, while the opposite was observed for fructose and raffinose (Table 3). No significant differences were detected in glucose, stachyose and mannitol concentrations of fine roots between the two sampling sites (Table 3 ).

\section{Enzyme activities}

In fine roots of trees growing at the polluted site, specific activities of sucrose-metabolizing enzymes, acid (AI) and neutral (NI) invertases and sucrose synthase (SuSy) were only insignificantly lower $(14-20 \%, \mathrm{P}>0.05)$ than in the control site. In contrast, the activities of enzymes associated with glycolysis (HK, FK and GAPDH) and the oxidative pentose phosphate pathway (G6PDH) were significantly lower than in the control site (Table 4).

\section{DISCUSSION}

\section{Soil characteristics}

The chemical characterization of the soil samples from the rooting zone of cottonwoods growing in the area of copper smelters "Głogów" revealed severe soil contamination with heavy metals (Table 2). Total $\mathrm{Cu}, \mathrm{Pb}, \mathrm{Cd}$ and $\mathrm{Zn}$ concentrations in the soil from the polluted site were similar to those recorded in the soil samples from the rooting zone of Calamagrostis epigejos and Elymus repens growing near "Głogów" (Lehmann and Rebele 2004) and also in contaminated soil from the vicinity of other copper smelters (Dinelli and Lombini 1996; Rebele et al. 1993). Copper and lead concentrations in the soil exceeded the critical levels $125 \mu \mathrm{g} \mathrm{g}^{-1} \mathrm{Cu}$ and $400 \mu \mathrm{g} \mathrm{g}^{-1}$ for $\mathrm{Pb}$, and indicate phytotoxicity (Allowey 1995).

The total concentration of a metal in the soil is not a valuable indicator of its mobility and availability to plants (Dai et al. 2004; Dinelli and Lombini 1996). The latter is better characterized by metal-EDTA extraction (Kabata-Pendias and Pendias 2001). The EDTA-extractable metal concentra- 
TABLE 3. Concentrations of starch (mg of glucose $\mathrm{g}^{-1} \mathrm{DW}$ ) and total nonstructural [TNC defined as a sum of soluble sugars (sTNC) and starch] carbohydrates (mg of glucose $\mathrm{g}^{-1} \mathrm{DW}$ ), and sucrose, glucose, fructose, raffinose, stachyose, galactose, mannitol ( $\left.\mathrm{mg} \mathrm{g}^{-1} \mathrm{DW}\right)$, and sucrolysis index (sucrose/hexoses) in fine roots of Populus deltoides ${ }^{\text {a }}$.

\begin{tabular}{lcc}
\hline Carbohydrate parameters & Control site & Polluted site \\
\hline Starch & $9.69 \pm 0.44$ & $13.02 \pm 1.42 *$ \\
TNC & $23.45 \pm 1.54$ & $28.49 \pm 2.14 *$ \\
sTNC & $15.08 \pm 1.14$ & $16.42 \pm 1.58$ \\
Sucrose & $5.71 \pm 0.47$ & $7.69 \pm 0.47 * *$ \\
Glucose & $2.46 \pm 0.18$ & $2.18 \pm 0.33$ \\
Fructose & $2.65 \pm 0.19$ & $2.02 \pm 0.22^{*}$ \\
Raffinose & $3.08 \pm 0.18$ & $1.94 \pm 0.12^{* * *}$ \\
Stachyose & $0.78 \pm 0.04$ & $0.72 \pm 0.06$ \\
Galactose & $0.46 \pm 0.03$ & $0.59 \pm 0.08^{*}$ \\
Mannitol & $0.64 \pm 0.11$ & $0.47 \pm 0.05$ \\
Sucrolysis index & $1.14 \pm 0.07$ & $1.64 \pm 0.17 * *$ \\
\hline
\end{tabular}

a Mean values \pm SE from 6-12 random samples. *, **, *** significantly different from the control at $\mathrm{P} \leq 0.05, \mathrm{P} \leq 0.01$ and $\mathrm{P} \leq 0.001$, respectively.

TABLE 4. Specific activities (nkat $\mathrm{mg}^{-1}$ protein) of enzymes catalyzing sucrose breakdown [acid invertase (AI), neutral invertase (NI) and sucrose synthase (SuSy)] or glycolysis [hexokinase (HK), fructokinase (FK) and glyceraldehyde 3-phosphate dehydrogenase (GAPDH)], and of an enzyme of the oxidative pentose phosphate pathway [glucose 6-phosphate dehydrogenase (G6PDH)], and concentration of soluble proteins $\left(\mathrm{mg} \mathrm{g}^{-1} \mathrm{FW}\right)$ in fine roots of Populus deltoides ${ }^{\mathrm{a}}$.

\begin{tabular}{lcc}
\hline Enzyme parameters & Control site & Polluted site \\
\hline AI & $5.06 \pm 0.35$ & $4.24 \pm 0.3$ \\
NI & $5.58 \pm 0.52$ & $4.93 \pm 0.54$ \\
SuSyb & $54.88 \pm 4.85$ & $47.99 \pm 4.24$ \\
HK & $1.26 \pm 0.15$ & $0.64 \pm 0.11 * *$ \\
FK & $1.03 \pm 0.14$ & $0.607 \pm 0.075^{*}$ \\
GAPDH & $0.33 \pm 0.03$ & $0.199 \pm 0.01 * *$ \\
G6PDH & $0.88 \pm 0.16$ & $0.28 \pm 0.04 * *$ \\
Soluble proteins & $8.87 \pm 0.62$ & $12.46 \pm 0.97 *$
\end{tabular}

a Mean values \pm SE from 6-12 random samples. *, ** significantly different from the control at $\mathrm{P} \leq 0.05$ and $\mathrm{P} \leq 0.01$, respectively.

b SuSy activity was assayed in crude extracts.

tions were lower than total concentrations in the control and polluted soils (Table 2). However, the proportion of total $\mathrm{Cu}(72 \%), \mathrm{Pb}(60 \%), \mathrm{Zn}(37 \%)$ and $\mathrm{Cd}(33 \%)$ contained in the EDTA extract was substantially higher in the polluted

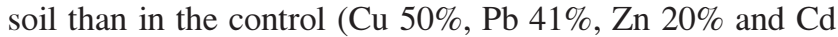
$24 \%$ ). It could be also expected that metal solubility and mobility will be enhanced because of the lower $\mathrm{pH}$ (Dai et al. 2004; Dinelli and Lombini 1996; Séguin et al. 2004) in the soil from the polluted site than in the control (Table 1).

\section{Carbohydrate metabolism in fine roots}

Total concentrations of nonstructural carbohydrates (TNC) in fine roots differ significantly between the two analyzed areas (Table 3). Concentrations of starch and soluble sugars were elevated in fine roots from the polluted site. An accumulation of carbohydrates in fine roots of trees growing in a soil contaminated with heavy metals seems to indicate inhibition of starch hydrolysis and disturbances in carbohydrate metabolism. Consistently with that suggestion, there was an increase in sucrose and a decrease in hexose concentrations and a rise in the sucrolysis index (i.e. sucrose/(glucose+fructose) (Table 3). These differences may reflect a blockage in the utilization of sugars in fine roots under heavy metal stress. On the other hand, the accumulation of carbohydrates in fine roots from the polluted site (Table 3 ) could be also partly a consequence of impaired nitrogen metabolism (Balsberg-Påhlsson, 1989) and $\mathrm{Ca}^{2+}$ deficiency (Greger and Bertell 1992), as total $\mathrm{N}$, $\mathrm{N}-\mathrm{NH}_{4}$ and $\mathrm{N}-\mathrm{NO}_{3}$ concentrations, and total $\mathrm{Ca}$ and Ca-EDTA extractable were significantly lower in the soil samples from the rooting zone of trees in the polluted area than in the control (Table 1). In fine roots from the polluted site, raffinose concentration was lowered and galactose concentration increased (Table 3 ), which could be related to formation of free radicals under the influence of toxic metals (Costa and Spitz 1997).

The catabolism of sucrose is mediated by invertases and sucrose synthase (Koch 2004). On the basis of $\mathrm{pH}$ optima and subcellular locations, sucrose synthase and both neutral and alkaline invertases are thought to be located in the cytoplasm, while acid invertases, in vacuoles (soluble forms) and the cell wall (insoluble forms) (Sturm 1999).

The specific activities of AI, NI and SuSy were slightly lower in fine roots from the polluted site than in the control (Table 4). Therefore, the increased sucrose level in fine roots from the polluted site could result not from lowered sucrolysis (then sucrose level would be constant) but probably from a greater capacity for sucrose synthesis (Jha and Dubey 2004) or efficiency of carbon allocation to roots (Liu and Tyree 1997).

HK and FK catalyze the first enzymatic reactions of glycolysis and GAPDH is a key enzyme in glycolysis and gluconeogenesis (Plaxton 1996). In fine roots from the polluted site, the specific activities of HK, FK and GAPDH were reduced (Table 4). Therefore, it could be speculated that heavy metal stress inhibited carbon flux in glycolysis. Consequently, a lowered production of carbon skeletons, ATP, reductants [NAD $(\mathrm{P}) \mathrm{H}]$, and pyruvate could be expected. Impairments in the generation of reducing power (NADPH) for anabolic pathway could be also due to the strong reduction of specific activity of G6PDH (Table 4), the main enzyme of the oxidative pentose phosphate pathway (Kruger and Von Schaewen 2003). On the other hand, decreased specific activities of HK, FR, GAPDH and G6PDH in fine roots from the polluted site could, at least partly, result from reduced levels of their substrates, i.e. glucose and fructose and phosphorylated hexoses.

In conclusion, the accumulation of soluble carbohydrates and starch deposition (Table 3), the increase in the level of soluble proteins and the changes in the specific activities of assayed enzymes (Table 4) observed in fine roots from the polluted site, are characteristic for a period of storage (Iraqi and Tremblay 2001; Loescher et al. 1990; Nguyen et al. 1990). Therefore we suggest that already in early October the growth and development of fine roots of poplar trees were stopped at the site contaminated with heavy metals. In the last three growing seasons we observed that leaf senescence and shedding were also earlier in those trees than in the control. This indicates that poplars (Populus deltoides) growing for several decades in polluted habitats are characterized by a shorter growing period.

\section{ACKNOWLEDGEMENTS}

This work was supported by grant no. 3 PO4G 07525 from the State Committee for Scientific Research, Poland. 
We wish to thank K. Grewling for skilful technical assistance.

\section{LITERATURE CITED}

ALLOWAY B.J. 1995. Heavy Metals in Soils. Chapman \& Hall, Glasgow UK.

ARDUINI I., GODBOLD D.L., ONNIS A. 1995. Influence of cooper on root growth and morphology of Pinus pinea L. and Pinus pinaster Ait. seedlings. Tree Physiol. 15: 411-415.

ARISI A.C.M., MOCQUOT B., LAGRIFFOUL A., MENCH M., FOYER C.H., JOUANIN L. 2000. Responses to cadmium in leaves of transformed poplars overexpressing gamma-glutamylcysteine synthetase. Physiol. Plant. 109: 143-149.

BALSBERG-PÅHLSSON A.-M. 1989. Effects of heavy-metal and $\mathrm{SO}_{2}$ pollution on the concentrations of carbohydrates and nitrogen in tree leaves. Can. J. Bot. 67: 2106-2113.

BRADFORD M.M. 1976. A rapid and sensitive method for the quantitation of microgram quantities of protein utilising the principle of protein-dye binding. Anal. Bioch. 72: 248-254.

BRECKLE S.-W. 1991. Growth under stress: Heavy metals. In: Plant Roots: The Hidden Half. Waisel Y., Eshel A., Kafkafi U., (eds), Marcel Dekker Inc., New York Basel Hong Kong, pp. 351-373.

BRUNNER I., BRODBECK S., WALTHERT L. 2002. Fine root chemistry, starch concentration, and 'vitality' of subalpine conifer forests in relation to soil pH. For. Ecol. Manage. 165: 75-84.

COPELAND L., DE LIMA M.L. 1992. The effect of aluminium on enzyme activities in wheat roots. J. Plant Physiol. 140: 641-645.

COSTA G., SPITZ E. 1997. Influence of cadmium on soluble carbohydrates, free amino acids, protein content of in vitro cultured Lupinus albus. Plant Sci. 128: 131-140.

DAI J., BEEQUER T., ROUILLER J. H., REVERSAT G., BERNHARD-REVERSAT F., LAVELLE P. 2004. Influence of heavy metals on $\mathrm{C}$ and $\mathrm{N}$ mineralisation and microbial biomass in $\mathrm{Zn}-, \mathrm{Pb}-, \mathrm{Cu}-$, and $\mathrm{Cd}-$ contaminated soils. Appl. Soil Ecol. 25: 99-109.

DI BACCIO D., TOGNETTI R., SEBASTIANI L., VITAGLIANO C. 2003. Response of Populus deltoides $\times$ Populus nigra (Populus $\times$ euroamericana) clone I-214 to high zinc concentrations. New Phytol. 159: 443-452.

DINELLI E. LOMBINI A. 1996. Metal distribution in plants growing on copper mine spoils in Northern Apennines, Italy: the evaluation of seasonal variations. Appl. Geochem. 11: 375-385 .

FARRAR J., POLLOCK C., GALLAGHER J. 2000. Sucrose and the integration of metabolism in vascular plants. Plant Sci. 154: 1-11.

GOUIA H., GHORBAL M.H., MEYER C. 2000. Effects of cadmium on activity of nitrate reductase and on other enzymes of the nitrate assimilation pathway in bean. Plant Physiol. Biochem. 38: 629-638.

GREGER M., BERTELL G. 1992. Effects of $\mathrm{Ca}^{2+}$ and $\mathrm{Cd}^{2+}$ on the carbohydrate metabolism in sugar beet (Beta vulgaris). J. Exp. Bot. 43: 167-173.

GREGER M., LINDBERG S. 1986. Effects of $\mathrm{Cd}^{2+}$ and EDTA on young sugar beets (Beta vulgaris). I. $\mathrm{Cd}^{2+}$ uptake and sugar accumulation. Physiol. Plant. 66: 69-74.

HO S.L., CHAO Z.C., TONG W.F., ZU S.M. 2001. Sugar coordinately and differentially regulates growth- and stress-related gene expression via a complex signal transduction network and multiple control mechanisms. Plant Physiol. 125: 877-890.

HUBER S.C. 1989. Biochemical mechanism for regulation of sucrose accumulation in leaves during photosynthesis. Plant Physiol. 91: 656-662.

IRAQI D., TREMBLAY F.M. 2001. Analysis of carbohydrate metabolism enzymes and cellular contents of sugars and proteins during spruce somatic embryogenesis suggests a regulatory role of exogenous sucrose in embryo development. J. Exp. Bot. 52: 2301-2311.

JHA A.B., DUBEY R.S. 2004. Carbohydrate metabolism in growing rice seedlings under arsenic toxicity. J. Plant Physiol. 161: 867-872.

KABATA-PENDIAS A., PENDIAS H. 2001. Trace elements in soils and plants. CRS Press LLC, Boca Raton.

KARACIC A., VERWIJST T., WEIH M. 2003. Above-ground woody biomass production of short-rotation Populus plantations on agricultural land in Sweden. Scand. J. For. Res. 18: 427-437.

KIM C.-G., POWER S.A., BELL J.N.B. 2003. Effects of cadmium and soil type on mineral nutrition and carbon partitioning in seedlings of Pinus sylvestris. Water, Air, Soil Pollut. 145: 253-266.

KOCH K. 2004. Sucrose metabolism: regulatory mechanisms and pivotal roles in sugar sensing and plant development. Curr. Opi. Plant Biol. 7: 235-246.

KRUGER N.J., VON SCHAEWEN A. 2003. The oxidative pentose phosphate pathway: structure and organisation. Curr. Opi. Plant Biol. 6: 236-246.

LANDBERG T., GREGER M. 2002. Differences in oxidative stress in heavy metal resistant and sensitive clones of Salix viminalis. J. Plant Physiol. 159: 69-75.

LAGRIFFOUL A., MOCQUOT B., MENCH M., VANGRONSVELD J. 1998. Cadmium toxicity effects on growth, mineral and chlorophyll contents, and activities of stress related enzymes in young maize plants (Zea mays L.). Plant and Soil 200: 241-250.

LEHMANN C., REBELE F. 2004. Evaluation of heavy metal tolerance in Calamagrostis epigejos and Elymus repens revealed copper tolerance in a copper smelter population of $C$. epigejos. Environ. Exp. Bot. 51: 199-213.

LIU X., TYREE M.T. 1997. Root carbohydrate reserves, mineral nutrient concentrations and biomass in a healthy and a declining sugar maple (Acer saccharum) stand. Tree Physiol. 17: 179-185.

LOESCHER W.H., MCCARMANT T., KELLER J.D. 1990. Carbohydrate reserves, translocation, and storage of woody plant roots. Hort. Sci. 25: 274-281.

LORENC-PLUCIŃSKA G., SZADEL A., PLUCIŃSKI A., PUKACKA S. 2001. Sucrose degradation in sink and source poplar leaves treated with sulfite. Acta Soc. Bot. Pol. 70: 209-214.

MATTIONI C., GABBRIELLI R., VANGRONSVELD J., CLIJSTERS H. 1997. Nickel and cadmium toxicity and enzymatic activity in Ni-tolerant and non-tolerant populations of Silene italica Pers. J. Plant Physiol. 150: 173-177.

NGUYEN P.V., DICKMANN D.I., PREGITZER K.S., HENDRICK R. 1990. Late-season changes in allocation of starch and sugar to shoots, coarse roots, and fine roots in two hybrid poplar clones. Tree Physiol. 7: 95-105.

PLAXTON W.C. 1996. The organization and regulation of plant glycolysis. Ann. Rev. Plant Physiol. Plant Mol. Biol. 47: 185$-214$

PULFORD I.D., WATSON C. 2003. Phytoremediation of heavy metal-contaminated land by trees - a review. Environ. Int. 29: 529-540.

PUKACKI P., KAMIŃSKA-ROŻEK E. 2002. Long-term implications of industrial pollution stress on lipids composition in Scots pine (Pinus sylvestris L.) roots. Acta Physiol. Plant. 24: 249-255.

REBELE F., SURMA A., KUZNIK C., BORNKAMM R., BREJ T. 1993. Heavy metal contamination of spontaneous vegetation and soil around the copper smelter "Legnica". Acta Soc. Bot. Pol. 62: 53-57.

ROBINSON B.H., MILLS T.M., PETIT D., FUNG L.E., GREEN S.R., CLOTHIER B.E. 2000. Natural and induced cadmiumaccumulation in poplar and willow: implications for phytoremediation. Plant and Soil 227: 301-306. 
ROITSCH T. 1999. Source-sink regulation by sugar and stress. Curr. Opi. Plant Biol. 2: 118-206.

SCHÜTZENDÜBEL A., POLLE A. 2002. Plant response to abiotic stress: heavy metal-induced oxidative stress and protection by mycorrhization. J. Exp. Bot. 53: 1351-1365.

SÉGUIN V., GAGNON C., COURCHESNE F. 2004. Changes in water extractable metals, $\mathrm{pH}$ and organic carbon concentrations at the soil-root interface of forested soils. Plant Soil 260: 1-17.

SMEEKENS S. 2000. Sugar-induced signal transduction in plants. Annu. Rev. Plant Physiol. Plant Mol. Biol. 51: 49-81.

STURM A., TANG G.Q. 1999. The sucrose-cleaving enzymes of plants are crucial for development, growth and carbon partitioning. Trends Plant Sci. 4: 401-407.

STURM A. 1999. Invertases. Primary structures, functions, and roles in plant development and sucrose partitioning. Plant Physiol. 121: 1-7.

SUNG S.S., KORMANIK P.P., BLACK C.C. 1993. Vascular cambial sucrose metabolism and growth in loblolly pine $(P i$ - nus taeda $\mathrm{L}$.$) in relation to transplanting stress. Tree Physiol.$ 12: 243-258.

SZADEL A., LORENC-PLUCIŃSKA G., KAROLEWSKI P., MATYSIAK R. 2003. Photochemical activity, photosynthetic pigments and carbohydrates in poplar leaves fumigated with sulphur dioxide. Dendrobiology 49: 57-61.

VAN ASSCHE F., CLIJSTERS C. 1990. Effects of metals on enzyme activity in plants. Plant Cell Environ. 13: 195-206.

VANDECASTEELE B., LAURIKS R., DE VOS B., TACK F.G. 2002. Cd and Zn concentration in hybrid poplar foliage and leaf beetles grown on polluted sediment-derived soils. Environ. Monit. Assess. 89: 263-283.

ZAMMIT A., COPELAND L. 1991. Purification and immunological properties of NAD-dependent glyceraldehyde-3-phosphate dehydrogenase from the plant cytosol of nitrogen fixing soybean nodules. J. Plant Physiol. 138: 44-50. 